International

Medical Society

http://imedicalsociety.org

\title{
Stigma and Prejudice Informed by Treated Lepers
}

\begin{abstract}
Arieli Rodrigues Nóbrega Videres ${ }^{1}$, Clélia Albino Simpson², Felismina Rosa Parreira Mendes ${ }^{3}$, Rita de Cássia Cordeiro de Oliveira ${ }^{4}$, Karinne Dantas de Oliveira Adário ${ }^{5}$, Emília Fernandes Pimenta ${ }^{6}$, Lenilde Duarte de Sá7
\end{abstract}

\section{Abstract}

Introduction: The segregation of people affected by leprosy in leper colonies as well as presenting itself ineffective, caused irreversible and irreparable consequences in the lives of individuals who came to carry the marks of stigma and prejudice surrounding the disease.

Objective: To identify traits related to the stigma and prejudice in the content of lepers' 12 speeches, separated compulsorily in Saint Francis of Assisi Colony in the city of Natal, located in the state of Rio Grande do Norte.

Method: Descriptive study focusing on the oral history of life. The narratives were collected in April 2010 through a recorded interview and analyzed by means of the technique of Thematic Content Analyses.

Results: The stigma and the prejudice crystallized in our culture had caused and still cause huge suffering and pain in the participants, who grew up and several aged in biological terms, living with a stigmatizing disease and its complications, sometimes disabling ones. In social and psychological terms, they were discriminated, rejected and even expelled from the familiar conviviality and the original social nucleus.

Conclusion: In this manner, one notices the need of these people recover their attachments, values and self-esteem, share feelings and build relationships so as to be integrated in the real world.
1 Nurse. PhD student of the Post graduate Program in Nursing at the Federal University of Paraíba. Assistant Professor of the Federal University of Campina Grande, Cajazeiras, *.

2 Nurse. Post-Doctorate from the University of Évora - Portugal. Professor of the Federal University of Rio Grande do Norte, Natal, Rio Grande do Norte, Brazil.

3 Nurse. PhD professor at the University of Évora, Portugal.

$4 \mathrm{PhD}$ in Nursing by the Graduate Program in Nursing at the Federal University of Paraíba. Professor of the University Center UNIPÊ, João Pessoa, *.

5 Nurse. Specialist in Health Service Management. Technical Advisor of the Labor Management Board on Health by the Municipal Health Department of João Pessoa, *.

6 Nurse. Master in Management in Organizations learners from the Federal University of Paraíba. Manager Work in Health by the Health Secretariat of the city of João Pessoa, Paraíba. Deputy Coordinator of the Teaching and Research Integrated Union (UNEPI).

7 Nurse. Professor Post, Department of Public Health Nursing and Psychiatry and the Graduate Program in Nursing at the Federal University of Paraíba, João Pessoa, * .

*: Paraíba, Brazil.

\section{Contact information:}

\section{Arieli Rodrigues Nóbrega Videres.}

Ð arieli.nobrega@hotmail.com

\section{Keywords}

Nursing; Leprosy; Prejudice 


\section{Introduction}

Throughout history, Hansen's disease, commonly known as leprosy, has been associated to various mystical meanings, as an impurity, dirtiness, divine punishment and curse, being described as a loathing and frightening disease, due to the presence of deformities and disabilities in untreated patient [1-2].

The distorted image that solidified the socio-cultural and religious imaginary from different societies and regions around the patient, accompanied by evidence of infectious or contagious nature of the disease, contributed to the strengthening of a treatment model based on the patient's restriction of freedom in large institutions of isolation, called leprosy [3].

The segregation of people affected by leprosy in these institutions lasted for decades in human history, as many believed this would be the most effective measure to prevent the spread of the disease and/or even eradicate it [2, 4-6]. However, it is clear that such a practice, not only presented itself ineffective, but also caused irreversible and irreparable consequences in the lives of those individuals who have come to carry the mark of stigmas and prejudice surrounding the disease [7-8].

Stigma term was created by the Greeks to refer to bodily signs with which it sought to show something extraordinary or bad about the moral condition of someone; a mark imposed by society to one of its members $[4,9,10]$. The individual who revealed a different behavior from the group would be deleted, because it would not fit the characteristics established by the community.

The word stigma presents different meanings. It may be related to the body's abominations, the individual character of guilt and social origin (nationality, religion, caste, etc.) $[4,11]$. In the context of leprosy, stigma refers to discredit, to disqualification and social marginalization as a consequence of physical deformities of the patient [10]. Once an individual is stereotyped with such a social label, which means to impose a mark that, in a way, reduces him to a lower condition than the minimum standard assigned to the human condition, two possibilities would remain to him: either suit with the marginal role assigned to him, or try to cover up the marks that characterize the stigmatizing stereotype [8].

For its part, the term prejudice as a judgment, an opinion or a feeling in which it formulates thoughtlessly, without foundation or reason, with regard to a person or group that doesn't know each other. It is accompanied by feelings of anxiety, disgust and terror, the last being capable of inspiring acts of terror. Furthermore, it causes measures of material or social segregation, which in turn favor ignorance, from the absence of knowledge or even the presence of misconceptions [12].

In this context, it recognizes the importance of knowing the history of the life of leprosy patients, primarily those who were segregated in leper coIonies or hospital colonies, in order to favor reflections about the denied or reversed citizenship for the family, society, and, especially to health professionals, so that they perceive the patient as someone not to be feared, but as a being endowed with bio-psycho-socio-spiritual needs, whose feelings, values and human rights must be respected.

Trying to understand the impact and the psychological and emotional repercussions caused by the disease in the routine and in the life of former patients, the question is: What are the evidences related to the stigma and prejudices experienced by people who have been treated for leprosy in an asylum manner?

It credits the relevance of the present study with views to contribute to record the historical aspects of the subjects, so that they are given a voice, action conferred by oral history. It is expected to provide inputs for managers and health professionals by encouraging awareness of the problem of stigma that reaches leprosy in the XXI century, 
so that effective strategies for social rehabilitation of the patient and former patient of leprosy are adopted looking towards the suppression of prejudice rooted in the image and history of the life of these individuals.

Thus, the study aimed at identifying marks related to the stigma and prejudice in the content of the speeches of people treated for leprosy, compulsory segregated in leper colonies.

\section{Method}

This is a descriptive study with a qualitative approach, in which a focus of oral history of life as a methodological reference was used, by considering the involvement of researchers with the object of study, in which they seek to unravel from registry of spontaneous and interactive testimonials about the history of life of employees involved, which are, the former leprosy patients with an asylum history.

In order to achieve better conditions for interviews, the study was conducted at the household level of collaborators who are residents in the neighborhoods Felipe Camarão , Km 6 and Jardim Américo, more precisely in the Conjunto Nova Vida, all located in Natal, a state of Rio Grande do Norte (RN).

It is worth emphasizing that the majority of collaborators reside in that quoted Conjunto, and that this constitutes a relevant figure in the construction of the life histories of those by consisting in a village of graduates built in a planned way in the 1990s, during the government of José Agripino, as a strategy for social reintegration of former carriers of leprosy who were segregated in the Colônia São Francisco de Assis, located in the municipality referred. Its name comes from this government proposal to offer a new life to those who for many years were considered undead.

In oral history, community of destiny refers to several groups that have common traits, notable from a broad behavior that characterizes them [13].In this sense, the target community of the study was made up of all former carriers of leprosy segregated in the the Colônia São Francisco of Assis, located in Natal (RN).

In turn, the colony, defined as a division in a large block of the target community which aims at understanding the intended whole and viability of the study [13], was composed of 12 of these individuals intentionally chosen from point zero, a depositary deponent of the group history or reference to stories of other partners [13]. The life story of the deponent Mattheus was considered the point zero of the study.

Considering the network as a subdivision of the colony that aimsto establish criteria to decide who should or not to be interviewed [13] were selected for the network of study collaborators independent of sex and without maximum age limit; who presented diagnosis of leprosy and lived in the Colônia São Francisco for a minimum of six months and; who agreed to participate voluntarily in the study. Hearing impaired and mentallyill were excluded from the collaborators net work.

The narratives of the life stories were seized in April 2010 through a structured interview, recorded, composed by the technical sheet containing the fictitious name, the age, education, marital status, religion, income, place of birth and two pre-formulated cutting questions, put into large blocks to assist in the narration of the significant events of these stories, which are: 1) Tell me your life as a former leprosy patient and 2) Tell me your experience as a resident of the Colony St. Francisco de Assis.

To preserve the anonymity of their true identities and avoid any embarrassment, collaborators were identified by fictitious names of biblical origin suggested by the researchers and chosen by them at the moment of the interviews.

The narratives were analyzed using the thematic content analysis technique, which requires a few 
steps that do not follow each other, obligatory, according to a chronological order, namely: pre-analysis; exploitation of material or codification; treatment of results, inference and interpretation [14].

The pre-analysis is the organization phase proper said through the systematization of ideas [14]. This time successive readings of the collected material were conducted to know all the texts and identify the similarities and significant points to the theme. Therefore, all interviews were registered by audio recording, transcribed in full and authorized by the collaborators. The texts have undergone minor linguistic adaptations, not eliminating, however, the spontaneous character of the talks.

The exploitation of the material corresponds to the transformation of data into thematic content through coding of the interviews, determining the themes to be discussed [14]. This was the most sustained period of analysis, which was conducted the inventory of all the lines, isolating, coding and cutting the registration unit (RU), defined assegment or characteristic speech stretch. The following UR were highlighted: visible and invisible marks; separation of the binomial parents $x$ children; fear of contagion; fire as punish ment and release; professional insecurity; symbolic death; identity crisis.

After, the categorization process occurred, in which the emerged categories of written statements, also known as core meaning, were made by a keyword that indicated the core meaning of the concept that was wished to grasp [14]. The RU conformed the following core meaning: Stigma and its impact on familyties of the deponent; Prejudice expressed intra and extramural Colony and Leprosy: A metamorphosed identity.

In the treatment of the results, inference and interpretation from the theoretical basis and assumptions that conducted the investigation were used [14].

The research project was submitted to the Research Ethics Committee (CEP) of the Federal University of Rio Grande do Norte (UFRN) being appro- ved by the appearing number 016/2010 according to Resolution No. 466/12 of the National Health Council (CNS), which deals with ethical aspects of research involving human beings.

\section{Results}

\section{Characterization of colaborators}

As for the characterization, a predominantly male collaborator profile is noted, almost all belonging to the third age group, with an average of 74 years old. Most were followers of a Catholic doctrine, native to the state of Rio Grande do Norte and did not have any level of schooling, being considered illiterate. Regarding marital status, half of the collaborators presented a stable union, married for over ten years and survived only from the federal pension benefit, receiving an average of two current national minimum wages, which corresponded to R \$520.00.

Thereby associating the variable schooling and family income, it was noticed that the collaborators belonged to the humble class of the people, thus presenting a low socioeconomic profile, which is something important to consider because this condition associated with the presence of physical disabilities can negatively impact the quality of life of individuals.

\section{Stigma and impact on the family}

The mark of leprosy is historical. Since ancient times as can be observed in biblical texts, this evil has been associated with several meanings. Consequently, the untreated diseased was seen as a being impure, unclean, deformed, fetid, untouchable, bearer of an ancient and unjust stigma that has been perpetuated in the minds of society to the present day. The speech below depicts the strong presence of this stigma attached to the terms leper and leprosy. 
Before, I was embarrassed to walk with those hands in the street, a leper! I walked with my hands in my pockets, hidden because I overheard when people said very softly: look the leper! We feel this. This disease affected me a lot, because people only spoke about the leper. This is a sad word. The only ones who know this business about the patient with leprosy is ourselves. The doctor said like this, 'do not let anyone call you a leper. Say this: Young man, call me patient, call me by my name, but do not say that word!'

André.

In the midst of so much suffering, some collaborators, in addiction to the stereotype of the physical and social scars, were forced to live with the anguish and the pain of separation from their children, who were taken to the primary school soon after birth, often inhumanely without presenting them to them. This can be observed in the speech below.

At the time the child is born, they pack them immediately and carry for us not to see, they don't even give them a bath. From seeing the couples suffering, I was already used to that moment. There wasn't anything that could be done, no one could solve anything because it was their law against ours.

Mateus.

In some fragments we see the sadness and indignation of the collaborators facing the separation of their children, and especially how this practice happened. This distancing caused irreversible consequences in the lives of parents and children, being the loss of bonding the most relevant with regard to the break of family ties and emotional suffering of the person who had leprosy. Such consequence is reported in the speech of a collaborator.
As time passed I had another son, who today is forty-six years old. He does not like me; he is ashamed of me because I am poor, sick and have this physical defect in the eye. Does not even want know me, lives there with the family of this doctor. I haven't seen him in three years. He calls everybody, but to me he does not make a call to see how I am.

Sara.

\section{Prejudice expressed intra and extramural Colony}

In this context of pain and suffering, prejudice concerning the former leper stigmatized and stereotyped in the mind of society since biblical times, was also present in the lives of collaborators.

The family didn't want anything to do with us because of the disease. They burned everything we had when we left the countryside. All that was ours, every little thing we had, even as poor, was all burned. They didn't want anything to do with us or our things because they were afraid of catching the disease.

Tomé.

Besides being forced to live with the stigma and the outside the walls prejudice, some collaborators have provided direct assistance to his companions when in critical condition or disability due to the fear expressed by some professionals of the Colony regarding the disease and the patient. Such behavior can be seen in the following speech.

There were nurses who would do the whole service, but there was another that wouldn't come even close when we were very sick. The other inmates did everything. There was a patient who was a nurse, Sir Oswaldo, he was as wise as any doctor. He said that anyone who had the disease would never get better.

Tadeu. 
These professionals, despite the scientific development of leprosy in relation to proof of its infectious-contagious character and the discovery of ambulatory and effective treatment, still, after years from deactivation of the colony live with the irreversible consequences of an ancient and unfair prejudice accompanied by feelings of anguish, horror and disgust, which are responsible for the emotional distress of collaborators.

There are people who live here who say that this group is of lepers. A lot of people here talk like that and that's why I think they might still have prejudice. Those older people when they meet me on the street are still afraid. Just to be bad, I come and say like this, 'You're still afraid of catching leprosy at this age? Even if you got it, there wouldn't be enough time for it to burst, because you would no longer be alive!

Pedro.

\section{Leprosy: a metamorphosed identity}

Leprosy causes changes and disorders in the public and private life of the patient, negatively influencing their emotional, social, economic and sexual life. Thus, emotional instability can develop and trigger a state of crisis, causing tensions and consequently physical, psychological and social changes that will result in the destabilization of the family and social relationships. Some collaborators revealed the installed crisis when the discovery of diagnosis and compulsory hospitalization.

I started to hate my whole entire family... my family was now the sick. I changed my identity, I began to adopt patients, employees and spiritualists who came to visit me as my family.

Pedro.

\section{Discussion}

An individual is a stigma carrier when he has any difference that constitutes a difficulty for acceptance by society [4]. The subject becomes the different, within a society that demands similarity and does not recognizing in the similarity, the differences. Without space, without voice, without papers and without function, one cannot be named and becomes a nobody, a nothing in relations with each other. The concept of stigma involves both the characteristics considered undesirable by society as well as the social context in which the stigmatized is inserted [10].

Leprosy causes changes in human perceptions and social and cultural relations, from the physical aspect that many of the patients may have over time, because of the side effects of the disease [5, 11]. In this way it could be noted in some lines that the leprosy image was associated with the presence of physical deformities.

It is also noticed that the collaborators besides suffering the consequences of the practice of compulsory isolation, such as, exclusion and prejudice, still had their lives marked by humiliation of being recognized solely as lepers. Even though this term has not been manifested in every speech, it is seen that the deformities and disabilities, left on their bodies for a long time contributed and still contribute to the strengthening of the stigma, selfstigma $[5,11]$ and prejudice responsible for their exclusion.

Furthermore, the strong presence of self stigmatization / marginalization in the stories of life of employees was also noted, since some of these called themselves leper during the course of the interviews, making clear a decrease in self-esteem and their psychosocial welfare $[6,11]$.

In the André's speech, when he says that he just walked with his hands in his pocket for he was ashamed to be known on the streets as a leper because of the deformities and scars left by the disease, such as blemishes and scars from the skin 
lesions, the collaborator externalizes the impact of stigma tax, perceived and internalized over the years, recognizing himself as a different being, not worthy of social life $[1,6]$.Or even, there is evidence of a clear prejudice existing in the way individuals see themselves. Through this speech, one sees the importance of supporting and strengthening the person affected by leprosy in order to propel them to recover their self-esteem.

Thus, it is clear that leprosy for centuries terrorized humanity cruelly, being considered as punishment, sin, karma, the need for spiritual cleansing and other forms of justifications [5].The suffering imposed on carriers of the disease crossed the tolerable limits of human dignity and resistance. The cruel and unjustified marginalization stamped the disease with a stigma deeply grounded, nourished by the lifeblood of prejudice that multiplies in humanity.

The stigma associated with prejudice brought negative repercussions not only for the lives of patients, but also for the lives of their children. They were responsible for the pain and suffering of the separation of sick parents and healthy children, where they were often abruptly removed from their parents at birth and sent immediately to the educational establishment to prevent infection and the spread of disease. The contact between them was minimal and usually the first was established years after the birth [9].

This discriminatory attitude caused the breakdown of family bonding with negative consequences that persist to this day. The speech of the collaborator Sara shows that this separation, associated with the presence of current physical deformities, was responsible for the loss of contact or even from despise of her son.

For its part, the prejudice associated with the fear of leprosy infection boosted the practice of ignorant and inhuman attitudes towards patients, such as burning their own bodies concomitant to their homes. This practice lasted for decades in the history of the disease as something quite common that aimed to ward off evils that endangered the healthy humanity and also purify the space inhabited by the patient and his family [15].

The burning of houses, belongings, and even the properties meant the symbolic death of the patient and his family to the environment they inhabited, thereby causing the loss of their identities, which were metamorphosed.

Prejudice rooted in socio-historical construction of the disease was also responsible for the presence of discriminatory attitudes of of the hospital-colony staff against the patients themselves, seeing them as a threat to their life. From these attitudes, studies reveal that one of the greatest difficulties encountered by hospitals-colonies consisted of hiring human resources to provide care to interns and coordinate the service of the institution because of the fear and dread that people had of becoming contaminated and socializing with scary, untouchable individuals. As a result, several inters became caregivers, thus compounding the nursing staff of those institutions [16-17].

Given the precariousness of nursing staff working in the colony as a direct consequence of prejudice, the high demand of the the sick and the commitment to quality of care, many patients voluntarily took the function of assistants or nursing aides, after being trained by the nurses. This reality, however, differs from other institutions, many of which patients were forced to assume this function. Some patients, often elderly or with physical side effects, had no right of choice, they were simply directed to the services and forced to work as nursing attendants to remain financially in the colonies [16].

Unfortunately, discriminatory attitudes, such as fear and ignorance, can still be seen in today's practice scenario. Studies show that patients with leprosy are denied their right to assistance when they cease to be attended in various specialties by prejudice of health professionals [8]. 
A study developed in Araçuaí health micro-region in the northeast of Minas Gerais, with many health professionals (doctors, nurses, managers, community health agents), pointed out that leprosy patients still fear to seek care in units of Primary Health Care in fear of having their diagnosis revealed and to be discriminated against by the other unit members, and/or even by the professionals themselves [7].

The rude way the collaborator Pedro behaved in front of a healthy individual upon meeting him on the street can be understood as a defense strategy against prejudice or preservation of self-esteem, given that in some cases, an unpleasant encounter between a healthy person and a patient, or former patient, makes the stigmatized individual become aggressive [8] or move away more and more from their social life, becoming depressed, hostile, anxious and confused or display aggressive attitudes generating embarrassing and unnecessary situations [5].

Leprosy is still configured as a poorly understood disease despite all the efforts of health policies for health education, because the slightest possibility of being affected by this disease causes fear and a negative impact on family and social life [18], by the fact that the illness can bring the memory of old and prejudiced ideas [19]. The magnitude of this impact is intrinsically related to prior knowledge about the disease $[2,20]$. So the fear of contagion due to lack of information about it can justify the exclusionary and discriminatory behavior of any civil, religious and family community against leprosy patients in past centuries.

It can be inferred that the stigma of leprosy was very prominent in Brazil by official health policies, based on confinement, justifying the breach of professional and emotional ties in the name of preserving the healthy safety [16]. Metaphorically, a death to the patient was imposed, this death, if not physically, socially, with the breaking of ties between the outside world to lepers [20]. At this point, many patients forced to abandon their homes, their work, their lifestyle and their friends, metamorphosed a new social identity, that is, that of lepers confined to leper colonies.

The stigmatized identity destroys attributes and qualities of the subject, has the power to control their actions and reinforces the deterioration of their social identity, emphasizing deviations and hiding the ideological character and stigmas. Society imposes the rejection, leads to loss of confidence in themselves and reinforces the symbolic character of social representation according to which the subjects are considered incapable and harmful to healthy interaction in the community. The social imaginary of the disease and of the unrecoverable is strengthened in order to maintain the effectiveness of the symbolic [21].

The dimensions affected by the identity crisis can be compared metaphorically to a set of threedimensional mirrors that affects how the individual sees himself as a carrier of the disease, being able to mask it or deny it; the way he wants to be seen by society and the way society sees him [21].

The harmful and relentless prejudice implicit in the expressions and attitudes of society against leprosy and against the bearers of this evil, caused the hospitalization of these individuals, who felt obliged to accept such a condition to get rid of the shame of having leprosy and also for believing in the promise of having a happy life in a beautiful and peaceful place and treatment against an evil, which was still little known in the early twentieth century. Consequently, their projects and dreams were shattered and their identities socially and morally erased, being obligated to incorporate a new social identity, namely that of institutionalized leprosy patients [16].

In this study, the collaborators demonstrate that they didn't lose their identities; they just underwent a process of metamorphosis as a strategy to adapt to their new life inside the colony. The isolation of leprosy patients in hospitals-colonies for a long time caused the diversion of their destiny and their identities within the family and society, being forced to 
live in a city inhabited by the disease and assume a new routine of life deliberated by others as well as a new identity, marked by prejudice and stigmas related to the disease [22].

Thus, it appears that, whether in society, in the family, in health professionals or the patient himself, the breaking of stigma process and prejudice against leprosy and its bearer is ancient and slow, since even beyond cure, its roots are resistant because its image is still associated with the presence of deformities and disabilities $[2,5]$.

\section{Conclusion}

It is recognized that the level of assistance in primary health care must always be focused on prevention and health surveillance activities, in which they must be carried out mainly through the orientation / education targeting the population. Thus, educative actions of prevention, group work aimed at reducing the stigma and improving the quality of life of the sick and people treated for leprosy are of fundamental importance for the control of the same.

Based on the considerations made, the need for an organized effort of all public health care facilities is evident, in the sense of acting creatively, participatory and dialogue on the issue of leprosy, prioritizing educational practice as a strategy of construction and reconstruction of knowledge among users, family, community and health team professionals.

\section{References}

1. Soomo F, Pathan G, Bhatti N, Hussain J. Awareness of leprosy knowledge and practices among general practitioners in leprosy endemic areas of Larkana region, Sindh, Pakistan. J Pak Assoc Derma. [Internet], 2013; 23(3): 300-03. Available from: http:// connection.ebscohost.com/c/articles/93444657/awarenessleprosy-knowledge-practices-among-general-practitionersleprosy-endemic-areas-larkana-region-sindh-pakistan.

2. Bittencourt LP, Carmo AC do; Leão AMM; Clos AC. Estigma: percepções sociais reveladas por pessoas acometidas por hanseníase. Rev enferm UERJ. [Internet], 2010; 18(2): 185-90. Available from: http://www.facenf.uerj.br/v18n2/v18n2a04.pdf.

3. Cunha VS. Isolados 'como nós' ou isolados 'entre nós'?: a polêmica na Academia Nacional de Medicina sobre o isolamento compulsório dos doentes de lepra. Hist Ciênc SaúdeManguinhos. [Internet], Rio de Janeiro, 2010; 17(4): 939-54. DOI: http://dx.doi.org/10.1590/S0104-59702010000400006.

4. Martins PV, Caponi S. Hanseníase, exclusão e preconceito: histórias de vida de mulheres em Santa Catarina. Ciênc Saúde Coletiva. [Internet], 2010; 15(Supl.1): 1047-54. DOI: http://dx.doi.org/10.1590/\$1413-81232010000700011.

5. Cid RDS, Lima GG, Souza Arde, Moura ADA. Percepção de usuários sobre o preconceito da hanseníase. Rev RENE. 2012; 13(5): 1004-14. Available from: http://www.repositorio.ufc.br/ handle/riufc/6182

6. Marinho FD, Macedo DCF, Sime MM, Paschoal VD, Nardi SMT. Percepções e sentimentos diante do diagnóstico, preconceito e participação social de pessoas acometidas pela hanseníase. Arq Ciênc Saúde. [Internet], 2014; 21(3): 46-52. Available from: http://repositorio-racs.famerp.br/racs ol/vol-21-3/IDZ-651-(213)-jul-Set-2014.pdf.

7. Lana FCF, Lanza FM, Carvalho APM, Tavares APN. O estigma em hanseníase e sua relação com as ações de controle. Rev Enferm UFSM. [Internet], 2014; 4(3):556-65. DOI: http://dx.doi. org/10.5902/2179769212550.

8. Neves IS, Rivemales MCC. Leprosy x social exclusion: updating study. Rev Enferm UFPE On line. [Internet], 2010; 4(1): 377-84. DOI: http://dx.doi.org/10.5205/01012007.

9. Abedi H, Javadi A, Naji S. An exploration of health, family and economic experiences of leprosy patients, Iran. Pak. J. Biol. Sci. [Internet], 2013; 16(18): 927-32. DOI: http://dx.doi.org/10.3923/ pjbs.2013.927.932.

10. Sermrittirong S, Van Brakel WH. O estigma da hanseníase: conceitos, causas e determinantes. Lepr Rev. 2014; 85(1): 36-47.

11. Adhikari B, Kaehler N, Chapman RS, Raut S, Roche P. Factors affecting perceived stigma in leprosy affected persons in western Nepal. PLoS Neg/ Trop Dis. [Internet], 2014; 8(6): 2940. DOI: http://dx.doi.org/10.1371/journal.pntd.0002940.

12. Borges E, Medeiros CA, D'Adesky J. Racismo, preconceito e intolerância. São Paulo: Atual; 2002. 
13. Meihy JCSB, Holanda F. História oral: como fazer, como pensar São Paulo: Contexto; 2007.

14. Bardin L. Análise de Conteúdo. Lisboa (Po): Edições 70; 2009.

15. Leite SCC, Sampaio CA, Caldeira AP. "Como ferrugem em lata velha": o discurso do estigma de pacientes institucionalizados em decorrência da hanseníase. Physis: Rev Saúde Coletiva. [Internet], Rio de Janeiro, 2015; 25(1): 121-38. DOI: http://dx.doi. org/10.1590/S0103-73312015000100008.

16. Gusmão APB, Antunes MJM. Ter hanseníase e trabalhar na enfermagem: história de lutas e superação. Rev Bras Enferm. [Internet] Brasília, 2009; 62(6): 820-4. DOI: http:// dx.doi.org/10.1590/S0034-71672009000600003.

17. Castro SMS, Watanabe HAW. Isolamento compulsório de portadores de hanseníase: memória de idosos. Hist Ciênc SaúdeManguinhos. [Internet], Rio de Janeiro, 2009; 16(2): 449-87. DOI: http://dx.doi.org/10.1590/S0104-59702009000200010.

18. Lanza FM, Vieira NF, Oliveira MMC, Lana FCF. Evaluation of the Primary Care in leprosy control: proposal of an instrument for users. Rev Esc Enferm USP. [Internet], 2014; 48(6): 1054-61. DOI: http://dx.doi.org/10.1590/s0080-623420140000700013.

19. Silva RCC da, Vieira MCA, Mistura C, Lira MOSC, Sarmento SS. Estigma e preconceito: realidade de portadores de hanseníase em unidades prisionais. J. res.: fundam. Care. [Internet], 2014; 6(2):493-506. DOI: http://dx.doi.org/10.9789/2175-5361.2014. v6i2.493-506.

20. Palmeira IP, Queiroz ABA, Ferreira MA de. Marcas em si: vivenciando a dor do (auto) preconceito. Rev Bras Enferm. [Internet], 2013; 66(6): 893-900. DOI: http://dx.doi.org/10.1590/ S0034-71672013000600013.

21. Miranda CAS. Hanseníase - o impacto da representação social e a crise identitária. João Pessoa: Ed. Universitária; 1999.

22. Mellagi AG, Monteiro YN. O imaginário religioso de pacientes de hanseníase: um estudo comparativo entre ex-internos dos asilos de São Paulo e atuais portadores de hanseníase. Hist Ciênc Saúde-Manguinhos. [Internet], Rio de Janeiro, 2009; 16(2): 489-504. DOI: http://dx.doi.org/10.1590/S010459702009000200011.
Publish in International Archives of Medicine

International Archives of Medicine is an open access journal publishing articles encompassing all aspects of medical science and clinical practice. IAM is considered a megajournal with independent sections on all areas of medicine. IAM is a really international journal with authors and board members from all around the world. The journal is widely indexed and classified Q1 in category Medicine. 